\title{
Strontium stratigraphy of the upper Miocene Lithothamnion Limestone in the Majella Mountain, central Italy, and its palaeoenvironmental implications
}

\author{
IRENE CORNACCHIA, PER ANDERSSON, SAMUELE AGOSTINI, MARCO BRANDANO AND \\ LETIZIA DI BELLA
}

LETHAIA

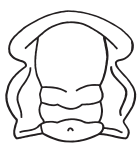

Cornacchia, I., Andersson, P., Agostini, S., Brandano, M. \& Di Bella, L. 2017: Strontium stratigraphy of the upper Miocene Lithothamnion Limestone in the Majella Mountain, central Italy, and its palaeoenvironmental implications. Lethaia, DOI: 10. 1111/let.12213.

\begin{abstract}
The ${ }^{87} \mathrm{Sr} /{ }^{86} \mathrm{Sr}$ isotope ratio has been widely used as a physical tool to date and correlate carbonate successions due to the long $\mathrm{Sr}$ residence time in comparison with the ocean mixing time. If this method works on oceanic successions, marginal basins may show different $\mathrm{Sr}$ isotope records in comparison with the coeval ocean one due to sea-level variations, continental run-off and restricted water exchanges. In this work, we present the ${ }^{87} \mathrm{Sr} /{ }^{86} \mathrm{Sr}$ isotope record of the upper Miocene carbonate ramp of the Lithothamnion Limestone (Majella Mountain, central Apennines), as an example of the onset of restricted water exchanges between a marginal basin and the ocean water masses. The overall latemost Tortonian-early Messinian Sr isotope record of the Lithothamnion Limestone fits below the global reference line. This deviation has been interpreted as due to the strong control that freshwater input and enhanced continental run-off, linked to the migration of the Apennine accretionary wedge and foredeep system, have had on the central Adriatic water chemistry. These results imply that an accurate oceanographic and geodynamic framework along with diagenetic overprint investigation has to be taken into consideration prior to apply SIS on carbonate successions on marginal basins, even when facies analyses indicate fully marine conditions. This seems to be the case for the upper Miocene Central Mediterranean carbonate successions, but may have more general validity and be extended to other recent or past marginal basins. $\square$ Apennines, Carbonate ramp, late Miocene, Mediterranean, Sr isotopes.
\end{abstract}

Irene Cornacchia $\bowtie[$ irene.cornacchia@uniroma1.it], Marco Brandano [marco.brandano@uniroma1.it], Letizia Di Bella [letizia.dibella@uniroma1.it], Dipartimento di Scienze della Terra, Sapienza Università di Roma, P. Aldo Moro 5, I-00185 Roma, Italy; Per Andersson [per.andersson@nrm.se], Department of Geosciences, Swedish Museum of Natural History, Box 50 007, SE-104 05 Stockholm, Sweden; Samuele Agostini [s.agostini@igg.cnr.it], Istituto di Geoscienze e Georisorse (IGG) CNR, Via Moruzzi 1, 56124 Pisa, Italy; manuscript received on 6/09/2016; manuscript accepted on 2/02/2017.

Strontium-isotope ratios have been widely used during the last thirty years to date and correlate carbonate successions (e.g. Burke et al. 1982; De Paolo \& Ingram 1985; McArthur 1994; Howart \& McArthur 1997; McArthur et al. 2001, 2012; Frijia \& Parente 2008; Brandano \& Policicchio 2012). This is because the $\mathrm{Sr}$ isotope ratio within the oceans has varied over geological time. The ${ }^{87} \mathrm{Sr} /{ }^{86} \mathrm{Sr}$ in sea water is mainly controlled by two different fluxes: continental weathering and ocean floor hydrothermal exchange and volcanism (Faure 1986; Palmer \& Edmond 1989; Taylor \& Lasaga 1999). The first controlling factor tends to increase the ${ }^{87} \mathrm{Sr} /{ }^{86} \mathrm{Sr}$ ratio, while volcanism enters into the oceans huge amounts of light ${ }^{86} \mathrm{Sr}$, lowering the overall Sr isotope signal. The strontium isotope stratigraphy (SIS) lies on the assumption that the ${ }^{87} \mathrm{Sr} /{ }^{86} \mathrm{Sr}$ into the oceans has always been homogeneous on a geological time-scale as the residence time of Sr into the ocean waters is $\sim 10^{6}$ years, thus much longer that the ocean mixing time, which is in the order of $10^{3}$ years. Relying on these assumptions, a global reference curve of the ${ }^{87} \mathrm{Sr} /{ }^{86} \mathrm{Sr}$ isotope ratios has been reported for the Phanerozoic (McArthur et al. 2001, 2012), and calibrated with biostratigraphy and magnetostratigraphy, or other stratigraphical tools. Thus, the comparison between the measured ${ }^{87} \mathrm{Sr} /{ }^{86} \mathrm{Sr}$ values of a sample and the calibrated curve yields an age for the sample.

However, if this method can work in ocean settings, it has become evident that within marginal basins the values of ${ }^{87} \mathrm{Sr} /{ }^{86} \mathrm{Sr}$ ratio can significantly differ from the coeval global means, due to variable influences of freshwaters, continental run-off, salinity changes and, eventually, local volcanism.

Analysing the Sr isotope record of the Late Pleistocene succession of the San Francisco Bay estuary, Ingram \& Sloan (1992) noted how it differed from the global Sr isotope ratio during sea-level lowstands 
and interpreted this difference as due to significant water salinity changes controlled by an increased freshwater input. Andersson et al. (1992) show how the Sr isotope signal in the brackish Baltic Sea can be treated as a mixing between the riverine signature and the sea water, and how it can locally differ, due to the different lithologies drained by the fluvial systems. On longer time-scales, and considering wider basins, Kocsis et al. (2008) interpret the lower ${ }^{87} \mathrm{Sr} /{ }^{86} \mathrm{Sr}$ ratios recorded in the lower Miocene carbonate successions of the Central Mediterranean as due to the contemporary, highly explosive, subduction-related volcanism developed within the western Mediterranean (Lustrino et al. 2009). If these results question the reliability of the SIS applied on marginal basins, on the other hand they imply that $\mathrm{Sr}$ isotopes can be a proxy of continental weathering and run-off and local palaeogeographical and palaeoceanographical reconstructions.

About 9-8 Ma, the ${ }^{87} \mathrm{Sr} /{ }^{86} \mathrm{Sr}$ isotope ratios of the Eastern and northern Mediterranean marginal basins start to decrease below the global reference line, showing the maximum deviation within the Lower Evaporites, during the Messinian salinity crisis (Schildgen et al. 2014). This deviation has been interpreted as mainly due to sea-level falls, together with basin uplift of the southern margin of Central Anatolia (Central Taurides), of the Apennines and the Sicilian Maghrebides, and thus to a progressive shallowing, which restricted the exchange of the Eastern and the proto-Adriatic basins, with the main Mediterranean water body (Flecker \& Ellam 2006; Topper et al. 2011; Schildgen et al. 2014). Different models have been published linking the late Miocene Mediterranean Sr isotope record to different controlling factors. For example, Flecker et al. (2002) and Flecker \& Ellam (2006) propose a non-dimensional steady state model where sea-level changes seem to be the major controlling factor on ${ }^{87} \mathrm{Sr} /{ }^{86} \mathrm{Sr}$ isotope ratios. Sea-level falls can lead to isolation and restrict water exchanges of marginal basins. On the contrary, Topper et al. (2011) provide a box model with time independent equations inferring that $\mathrm{Sr}$ isotope variations are mostly affected by riverine input into restricted basins which lead to salinity changes.

In this work, the $\mathrm{Sr}$ isotope record of the upper Miocene carbonate ramp succession, represented by the Lithothamnion Limestones (LL) cropping out in the Majella Mountain (Central Apennine, Italy) and in the exploration wells of Adriatic Sea (Brandano et al. 2016a), is presented. The LL offers an opportunity to study the evolution of a marginal basin within the Mediterranean such as the Adriatic Sea. This lithostratigraphic unit records the final steps of Apennine orogenesis when the proto-Adriatic area started developing. The aim of this work was to evaluate how the geodynamic evolution of this basin may have influenced the marine Sr isotope values and consequently impacted the SIS of the upper Miocene succession of the Adriatic area.

\section{Geological setting}

The Majella Mountain is a N-S/NW-SE oriented thrust-related anticline that plunges both North and South (Fig. 1A, B). It consists in the northern extension of the Apulia carbonate platform, and together with the Latium-Abruzzi, it represents one of the two carbonate platform domains of the Central Apennine fold-and-thrust belt (Patacca et al. 2008; Vezzani et al. 2010). The Majella Mountain sedimentary succession consists in Upper Jurassic to upper Miocene limestones and dolostones (Crescenti et al. 1969). During the Mesozoic a steep, erosional escarpment separated the shallow-water carbonates from the basin, extending northward (Fig. 1C) (Vecsei et al. 1998). During the late Campanian, the platform prograded over the basin, as it was completely filled by onlapping sediments, and evolved into a distally steepened ramp with the adjacent slope (Mutti et al. 1996; Vecsei et al. 1998). The Palaeogene evolution of the Majella platform is represented by Santo Spirito Formation characterized by a continuous sedimentation along the platform margin and the slope, while the top shows long-term hiatuses and discontinuous deposits (Vecsei et al. 1998). A discontinuity surface separates the Santo Spirito Formation from the overlying Bolognano Formation (late Rupelian-Messinian) that represents another carbonate ramp, developing above the shallow-water deposits of the former platform (Mutti et al. 1997; Brandano et al. 2012, 2016b). The Bolognano Formation has been divided into several informal members (Fig. 2) (Mutti et al. 1997, 1999; Carnevale et al. 2011; Brandano et al. 2012, 2016b). The first unit, Rupelian to late Chattian in age, is represented by the Lepidocyclina Limestones 1 (Brandano et al. 2012, 2016b). It mainly consists of cross-bedded packstones to grainstone with Larger

Fig. 1. A, schematic geological map of Italy (modified after Pomar et al. 2004). B, simplified geological map of the Majella Mountain (modified after Vecsei \& Sanders 1999), with section locations; 1, Costa dell'Avignone; 2, Roccamorice; 3, Fonte Macchialonga. C, schematic architecture of the Majella carbonate platform (modified after Vecsei et al. 1998). 

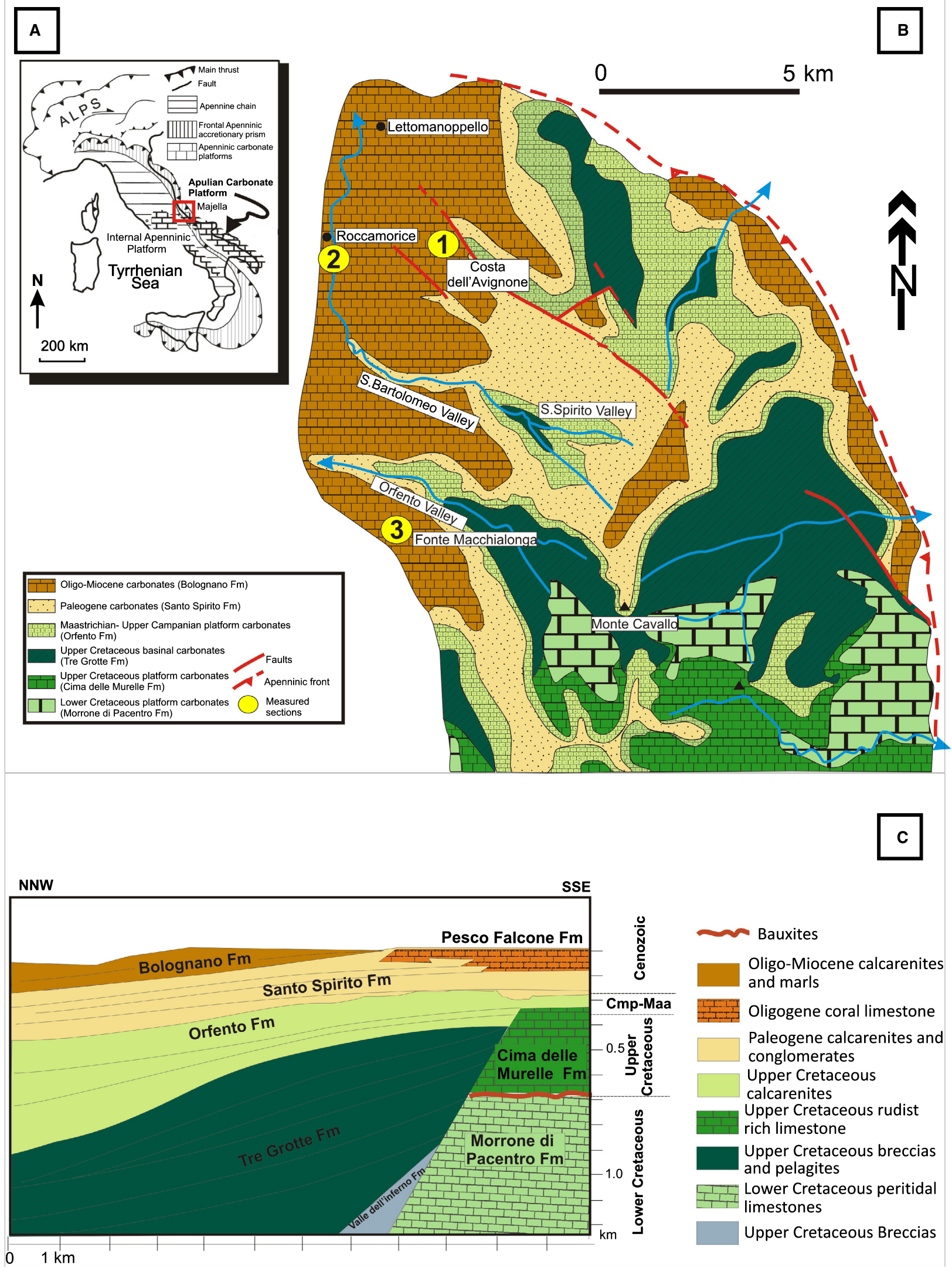
Benthic Foraminifera and represents a wide dune field developed within the middle ramp environment, under the action of strong northward, basinward-directed, storm-related currents (Brandano et al. 2012). During the late Chattian-late Aquitanian time interval, the Lepidocyclina Limestones 1 carbonate ramp drowned and it is overlain by a marly cherty unit, which represents the sedimentation on an outer ramp depositional environment, developed within the aphotic zone (Brandano et al. 2016b). From the late Aquitanian to the late Burdigalian, the Lepidocyclina dominated carbonate factory faced a recovery (Lepidocyclina Calcarenites 2 of Brandano et al. 2012, 2016b), drowning eventually in the late Burdigalian. This event is marked by a phosphatic hardground surface cropping out throughout the entire Bolognano Formation. Two different units lie above this hardground surface: a bryozoan-dominated coarse calcarenitic unit, the thickness of which rapidly decreases northwards, laterally passing into a hemipelagic calcareous-marly unit. Both these units can be ascribed to the late Burdigalian-Serravallian time interval (Brandano et al. 2016b). Above the hemipelagic marly limestones, the third shallow-water unit occurs: the Lithothamnion Limestone (Brandano et al. 2016a,b). The LL unit is capped by the deposition of the 'Turborotalita multiloba hemipelagic marls' (Carnevale et al. 2011), followed by the Gessoso-Solfifera Formation (Crescenti et al. 1969). Lastly, during the early Pliocene, the Majella Mountain was involved into the foredeep system of the Apennine orogeny (Cosentino et al. 2010).

\section{The Lithothamnion Limestone}

The Lithothamnion Limestone (LL) unit is made by up to $30 \mathrm{~m}$ of limestones to marly limestones dominated by red algae and subordinated bivalves. The depositional model is consistent with a homoclinal ramp profile, characterized by a wide middle ramp environment dominated by red algae branches representing the maërl facies (Brandano et al. 2016a). The inner ramp is characterized by coral build-ups, cropping out in the southernmost portion of the Majella Mountain (Danese 1999), passing basinward to seagrass meadows that interfinger with the maërl facies. The outer ramp consists in bioturbated marly limestones and marls with pectinids, small benthic and planktonic foraminifera (Brandano et al. 2016a). Two main stratigraphical intervals may be recognized in the LL unit. The lower interval (lower LL) is dominated by red algal branches that decrease in the upper portion (upper LL) while the terrigenous input increases. The base of the upper LL is marked by the presence of the Bioclastic Packstone and the Red Algal Bindstone. Moreover, the uppermost portion is characterized by the presence of two different brachiopods-rich levels, where populations of Terebratula sinuosa have been identified (Sirna 1996).

\section{Material and methods}

Three stratigraphical sections, cropping out in the NW sector of the Majella Mountain, have been sampled for strontium isotope stratigraphy (SIS) and micro-palaeontological analyses. The first two sections crop out, respectively, within the Lettomanoppello area (Costa dell'Avignone) and the Roccamorice village, while the third (Fonte Macchialonga) is exposed within the Orfento Valley (Figs 1B, 3).

Ten different specimens of bivalves and brachiopods have been analysed for SIS. A complete diagenetic screening (trace element concentrations and stable isotope ratios) has been performed on the sampled shells. $\mathrm{Mg}, \mathrm{Mn}, \mathrm{Fe}, \mathrm{Sr}$ and $\mathrm{Ba}$ concentrations

NNW SSE

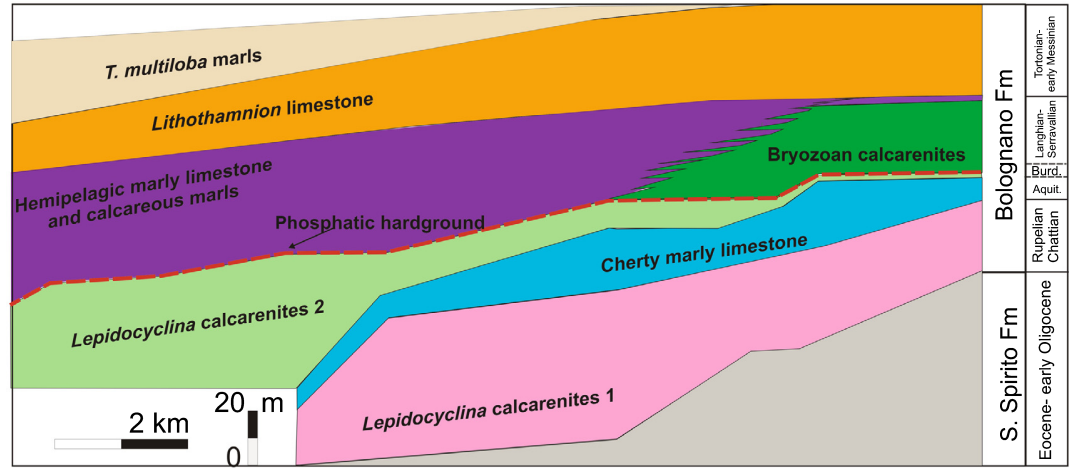

Fig. 2. Stratigraphical architecture of the Bolognano Formation (modified after Brandano et al. 2016b). 
have been measured on polished thin sections using the CAMECA electron microprobe of the Istituto di Geologia Ambientale e Geoingegneria (IGAG-CNR) at Sapienza, University of Rome. The same specimens have been powdered with a hand-operated microdrill, using $0.5 \mathrm{~mm} \varnothing$ tungsten drill bits, avoiding the external and evidently altered portions, for both stable $\mathrm{C}$ and $\mathrm{O}$ and radiogenic $\mathrm{Sr}$ isotope ratios measures. Carbon and oxygen stable isotopes have been measured at the isotope geochemistry laboratory of the Istituto of Geologia Ambientale e Geoingegneria (IGAG-CNR) of Rome, using a gas chromatographybased Gas Bench II coupled with a FINNIGAN Delta Plus mass spectrometer. The results were calibrated using the NBS19 carbonate standard. Both $\delta^{13} \mathrm{C}$ and $\delta^{18} \mathrm{O}$ values are reported on the Pee Dee belemnite (PDB) scale. The analytical error is $\pm 0.1 \%$ based on replicate standards.

$\mathrm{Sr}$ isotope ratios have been measured at the Department of Geosciences of the Natural History Museum of Stockholm (NRM) using a Thermo Scientific TRITON mass spectrometer. Separation of $\mathrm{Sr}$ has been performed in $\mathrm{Sr}$-spec and TRU resins mixed columns. Measured ${ }^{87} \mathrm{Sr} /{ }^{86} \mathrm{Sr}$ ratios have been normalized to ${ }^{86} \mathrm{Sr} /{ }^{88} \mathrm{Sr}=0.1194$. During the collection of the Sr isotope data, 12 replicate analyses of the NIST SRM 987 standard gave an average value of $0.710226 \pm 0.000014(2 \sigma)$ and all measured ratios have been corrected to this value.

The ${ }^{87} \mathrm{Sr}^{86} \mathrm{Sr}$ values of the unaltered samples have been converted to numerical ages using Version $4 \mathrm{~B}$ : 08/04 of the Look-Up Table of Howart \& McArthur (1997), for details of 4B: 08/04 see McArthur \& Howarth (2004). Minimum and maximum ages were calculated by combining the long-term standard error $(2 \sigma)$ of each measured ${ }^{87} \mathrm{Sr} /{ }^{86} \mathrm{Sr}$ value with the uncertainty of the strontium-isotope curve (Howart \& McArthur 1997).

Five samples belonging to the upper portion of the LL have been analysed to identify their microfossil content for biostratigraphical purposes. The lithified samples were disaggregated first in acetic acid $80 \%$, and then in an ultrasonic cleaner, according to the procedure described by Lirer (2000). The disaggregated material has been wet-sieved in a 63$\mu \mathrm{m}$ sieve to separate the clay fraction before the observation.

\section{Results}

\section{Stratigraphy of sampled sections}

Costa dell'Avignone section. - In this section, only the lowest interval of the LL unit crops out (Fig. 3).
In the Lettomanoppello area, the LL overlays the hemipelagic marls and marly limestones unit described by Brandano et al. (2016b) (Fig. 2). The base of the section consists of a 1-m-thick interval of a cross-bedded bioclastic packstone with bivalves and vertebrate bones (Figs 3, 4A, 5A). This unit culminates in a lag deposit with bivalves where the most common genera are Flabellipecten and Pecten. This facies is overlain a $3-\mathrm{m}$-thick interval represented by a free-living red algal branch floatstone to rudstone where the major components are coralline algae unattached branches characterized by a low-density branching, together with small rhodoliths. The matrix is represented by a poorly sorted bioclastic packstone with small benthic and encrusting foraminifera.

Four pectinid shells (CAP0, CAP1, CAP2 and CAP3) have been sampled from two different strata, $50 \mathrm{~cm}$ spaced one from another, belonging to the lower LL interval, cropping out at the base of the section (Fig. 3).

Roccamorice section. - As in the Lettomanoppello area, also in the Roccamorice section, the LL unit overlays the hemipelagic marls and marly limestones unit described by Brandano et al. (2016b) (Fig. 2).

Here, the lower interval of LL consists of a $20-\mathrm{cm}-$ thick bed of a Heterostegina floatstone to rudstone (Fig. 5B), followed by $15 \mathrm{~m}$ of a free-living branches floatstone to rudstone (Fig. 4B, C), alternated with a bioclastic packstone facies. The free-living red algal branch floatstone to rudstone consists in limestones to marly limestones dominated by unattached branches of coralline algae and small rhodoliths (Fig. 5C, D). The major components are usually dispersed in a poorly sorted bioclastic matrix mostly made of small benthic foraminifera, together with encrusting foraminifera, which occasionally show hooked shapes. The bioclastic packstone, on the contrary, consists of 20 to $40-\mathrm{cm}$-thick lenticular beds, usually poorly sorted. The main components are small benthic foraminifera as rotaliids, buliminids, encrusting foraminifera, planktonic foraminifera, serpulids, echinoid, bryozoan and bivalve fragments. Red algal fragments are usually subordinated. The upper LL is represented by $10 \mathrm{~m}$ of medium-grained bioclastic packstone. A constant increase of the terrigenous input is evident, as testified by a few centimetre-thick marly interstrata that interrupt the bioclastic packstone deposition.

Samples for SIS belong to three different layers (Fig. 3). Sample RP1a, collected $1.20 \mathrm{~m}$ above the base of the upper LL, is a pectinind shell. RP2 and RP2a and RP3 samples, belonging to two different brachiopod-rich intervals, respectively, at $11.40 \mathrm{~m}$ 
Roccamorice

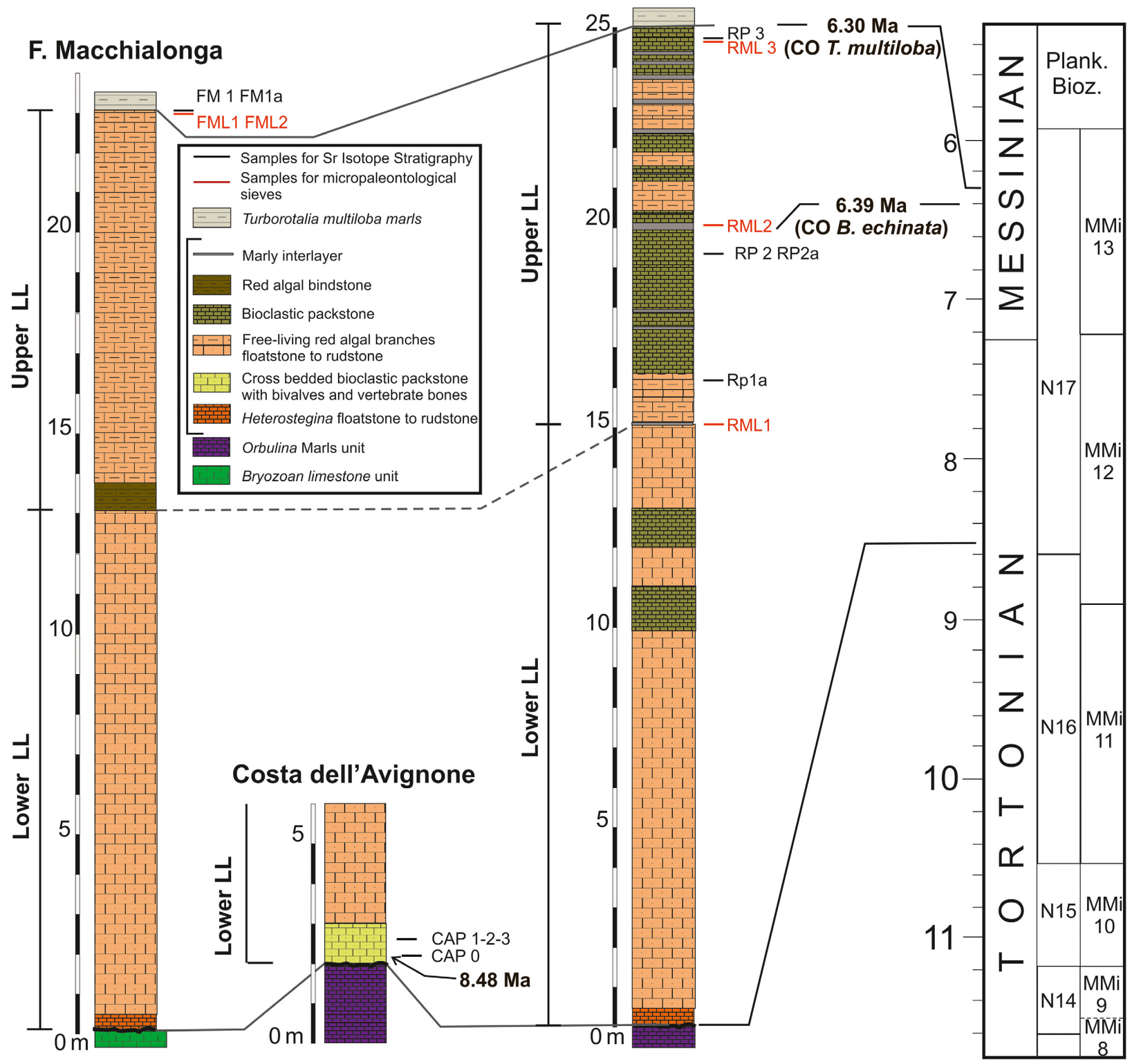

Fig. 3. Correlation of the measured sections, plotted against stratigraphical depth, and sample locations. Planktonic foraminifera Nzones are referred to Blow (1969), and MMi-zones are according to Iaccarino (1985). The age of the base of the lower Lithothamnion Limestone is provided by SIS; ages of the CO of the Bulimina echinata and the Turborotalita multiloba are derived from Kouwenhoven et al. (2006).

and at the top of the section, are Terebratula sinuosa brachiopods (Fig. 3).

Three different marly layers, the first one at the base of the upper LL, the second at $20 \mathrm{~m}$ and the third at the top of the section, have been sampled to analyse their micro-fossil content (samples RML1, RML2, RML3) (Fig. 3). All the samples show foraminiferal content with variable frequencies. In detail, RML1 and RML2 are characterized by typical infralittoral foraminifera represented mainly by Elphidium spp. (E. complanatum, E. crispum) and Asterigerinata spp. (e.g. A. planorbis). Particularly, RML2 shows a more abundant micro-fossil content with a better preservation in respect of the RML1 sample. In addition, in RML2 sample, a more diversified assemblage, characterized by epiphyte taxa like Lobatula lobatula and Rosalina spp., is recorded. Subordinately, infaunal taxa, belonging to Brizalina/Bolivina and Bulimina genera (e.g. Bolivina arta, Bulimina aculeata, Bulimina echinata) (Fig. 6), and agglutinated species, mainly represented by Textularia genus, are also present. Planktonic taxa are very rare or totally absent. 

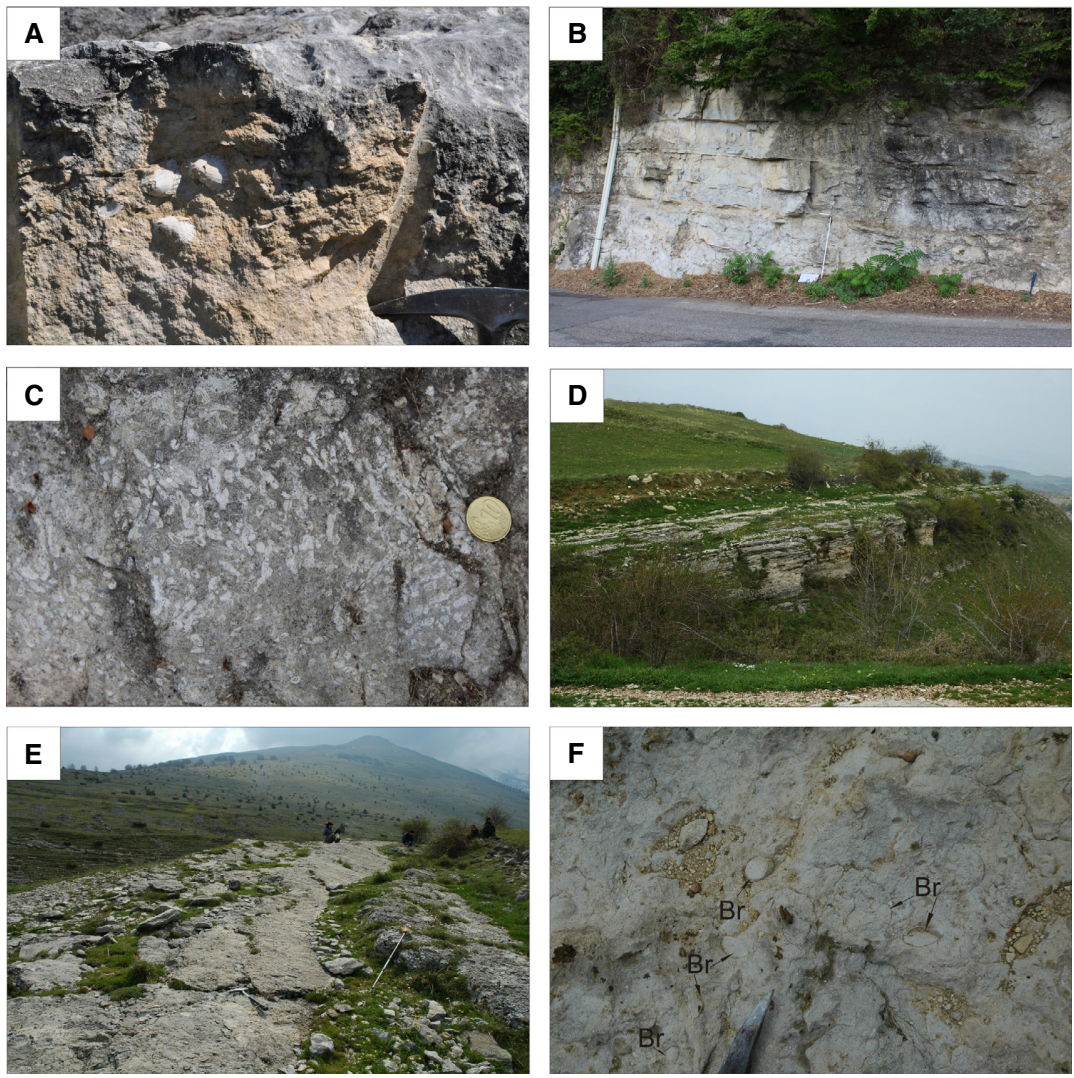

Fig. 4. Main lithofacies of the Lithothamnion Limestone (LL). A, Detail of Pecten specimens cropping out at the base of the lower LL interval in the Costa dell'Avignone section. B, Upper portion of the lower LL of the Roccamorice section. C, Detail of the free-living red algal branch floatstone to rudstone (maërl facies) of the lower LL in the Roccamorice section. D, Upper LL interval in the Fonte Macchialonga section. E, Brachiopod floatstone at the top of the LL unit outcropping in the Fonte Macchialonga section. F, Detail of the brachiopod floatstone in the Fonte Macchialonga section. For further information on the main lithofacies of the LL, see Brandano et al. (2016a).

The upper sample of the section (RML3) shows a very low foraminiferal content. A sharp decrease of infralittoral taxa is recorded whereas only rare mud dwellers buliminids dominate the benthic assemblage; among these, Bulimina aculeata and Bulimina echinata are found. The plankton fraction is very rare and represented by Globigerinoides spp. and small globigerinids.

Fonte Macchialonga section. - Unlike in the Lettomanoppello and Roccamorice areas, within the Orfento Valley the LL lays on the Bryozoan calcarenites unit described by Brandano et al. (2016b) (Fig. 2).

The lower LL in the Fonte Macchialonga section consists of $50 \mathrm{~cm}$ of the Heterostegina floatstone to rudstone, followed upward by $12.5 \mathrm{~m}$ of the free-living red algae floatstone to rudstone facies (Fig. 5E). The upper LL displays, at the base, a 70-cm-thick stratum of a red algal bindstone. The red algal bindstone facies consists in a tabular bed of nodular limestones dominated by thin red algae crusts (Fig. 5F). The red algal bindstone is followed by 9.30 metres of free-living red algae branches floatstone to rudstone (Fig. 4D). As in the Roccamorice section, the upper LL shows a progressive increase of the terrigenous input. The top of the section consists in a bioturbated, marly floatstone with brachiopod shells, among which the Terebratula sinuosa is the most common species, and encrusting bryozoans (Fig. 4E, F). The brachiopod-rich level from the top of the section has been sampled for both SIS and biostratigraphical purposes. The micro-fossil content from FML1 and FML2 samples (upper portion of upper LL) (Fig. 3) is characterized by small benthic foraminifera belonging mainly to Bulimina and Bolivina genera among which Bulimina echinata and Bolivina paralica have been identified. Moreover, in both samples, rare specimens of Valvulineria bradyana, Eponides sp., Guttulina spp. and Fissurina spp. are found with frequent planktonic taxa like Orbulina bilobata, O. universa, Globigerinoides spp., and small globigerinids. 

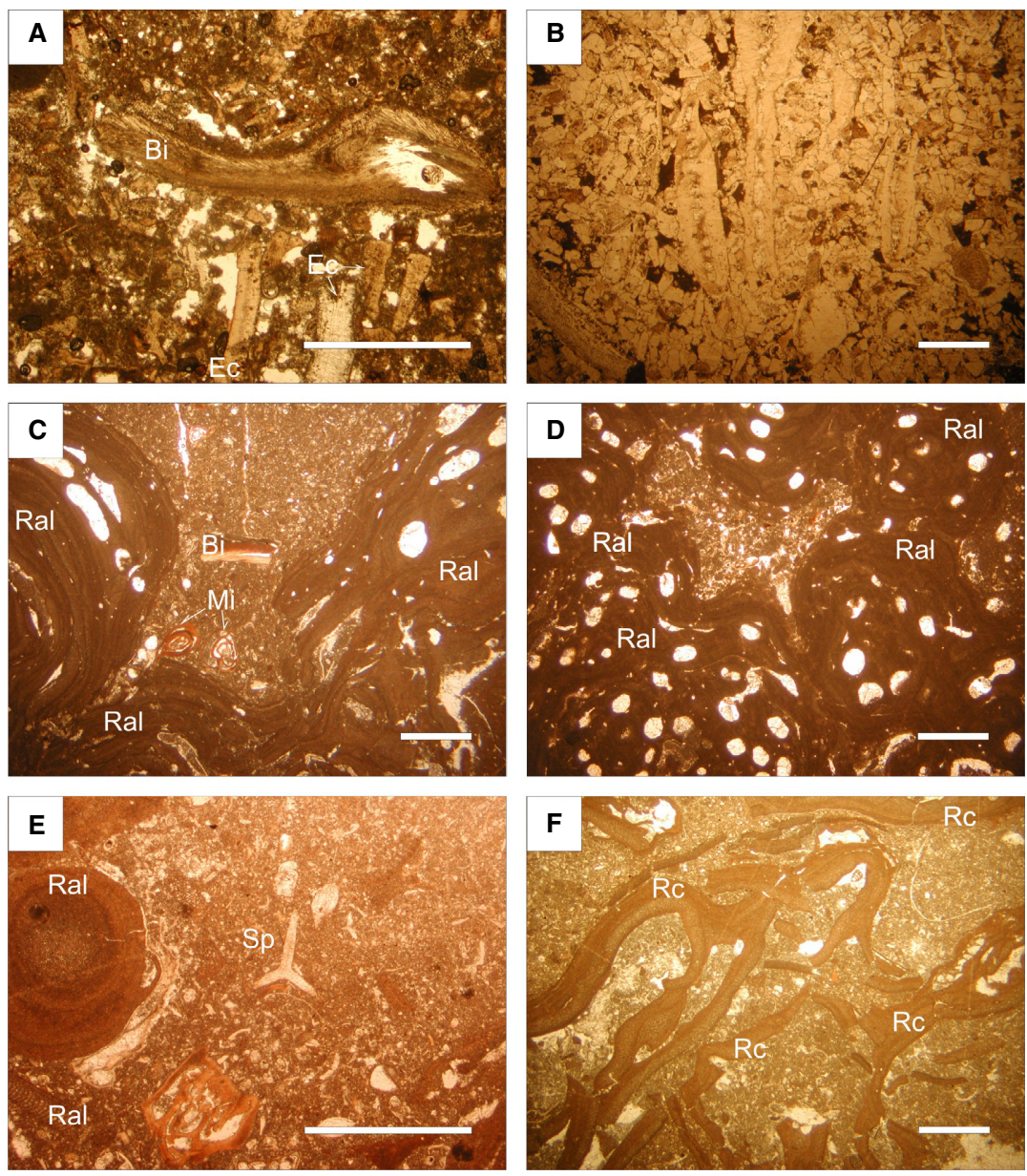

Fig. 5. Main microfacies of the Lithothamnion Limestone (LL). A, cross-bedded bioclastic packstone with bivalves and vertebrate bones. $\mathrm{B}$, Heterostegina floatstone. $\mathrm{C}-\mathrm{E}$, free-living red algal branch floatstone to rudstone. $\mathrm{F}$, red algal bindstone; $\mathrm{Bi}=$ bivalve fragment; $\mathrm{Ec}=$ echinoid fragment; $\mathrm{Mi}=$ miliolids; $\mathrm{Ral}=$ red algae; $\mathrm{Rc}=$ red algal crust; $\mathrm{Sp}=$ sponge spicule. Scale bar $=1 \mathrm{~mm}$. For further information on the main micro-facies of the LL, the reader is referred to Brandano et al. (2016a).

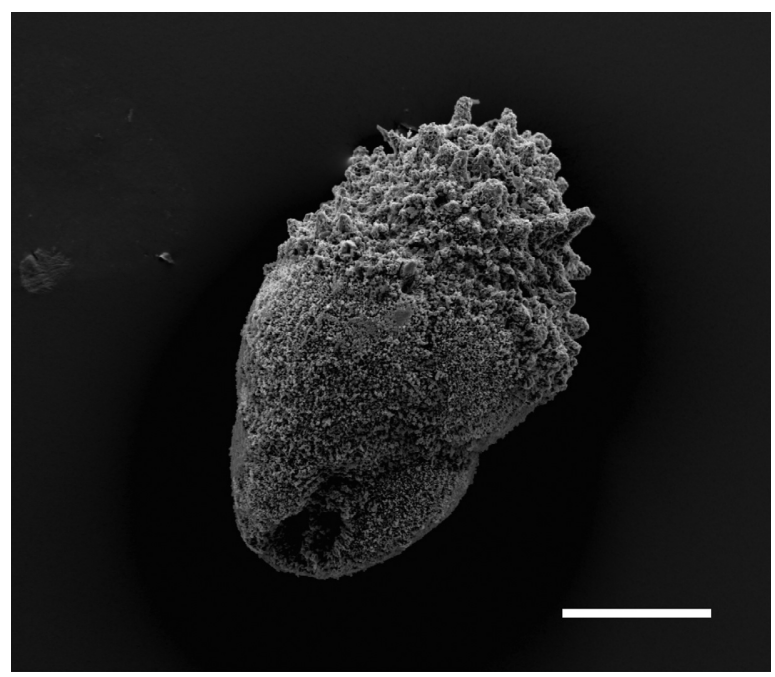

Fig. 6. Scanning electron micrograph of a Bulimina echinata specimen belonging to the Upper LL cropping out in the Roccamorice section. Scale bar $=100 \mu \mathrm{m}$.

\section{Screening for diagenetic overprint and SIS}

Before applying SIS, the preservation state of the samples must be assessed. Bivalves and brachiopods have been extensively used as proxies of the chemical composition of sea water (Veizer et al. 1997, 1999; Wenzel 2000; Brand et al. 2003; Immenhauser et al. 2016). Their L-Mg calcite shells, in fact, are quite resistant to diagenetic alteration (Brand \& Veizer 1980; Longman 1980; Morse \& Mackenzie 1990), and thus, they are considered a reliable proxy of the $\mathrm{Sr}$ isotope composition of the ambient water (McArthur 1994; Veizer et al. 1997, 1999; Steuber 1999; McArthur \& Howarth 2004; Frijia \& Parente 2008; Brandano \& Policicchio 2012; Frijia et al. 2015). The L-Mg calcite diagenesis tends to decrease the Sr concentrations of the shells, while Fe and Mn increase (Brand \& Veizer 1980). The Sr isotope ratio have been measured on different specimens of 
Table 1. Trace element concentrations profiles of $\mathrm{Mg}, \mathrm{Mn}, \mathrm{Fe}, \mathrm{Sr}$ and $\mathrm{Ba}$, reported as mean values of the pectinid and brachiopod shell samples. $\delta^{13} \mathrm{C}$ and $\delta^{18} \mathrm{O}$ values reported on the VPDB scale.

\begin{tabular}{|c|c|c|c|c|c|c|c|}
\hline Sample & $\mathrm{Mg}(\mathrm{ppm})$ & $\mathrm{Mn}(\mathrm{ppm})$ & $\mathrm{Fe}(\mathrm{ppm})$ & $\mathrm{Sr}(\mathrm{ppm})$ & $\mathrm{Ba}(\mathrm{ppm})$ & $\delta 13 \mathrm{C}(\% \mathrm{VPDB})$ & $\delta 18 \mathrm{O}(\% \mathrm{VPDB})$ \\
\hline CAP0 & 1285.46 & 69.37 & 190.90 & 1009.98 & 219.52 & 1.92 & 1.10 \\
\hline CAP1 & 2074.10 & 8.86 & 118.80 & 552.18 & 101.76 & 0.76 & 0.64 \\
\hline CAP2 & 1047.90 & 73.51 & 185.38 & 516.24 & 183.20 & 1.33 & 0.67 \\
\hline CAP3 & 2596.61 & 141.46 & 79.91 & 1078.81 & 45.66 & 0.17 & 0.77 \\
\hline RPla & 2961.18 & 105.92 & 183.44 & 1099.49 & 64.24 & -0.32 & 0.25 \\
\hline RP2 & 2323.96 & 10.63 & 68.09 & 654.15 & 0.00 & -0.05 & 2.64 \\
\hline RP2a & 983.91 & 121.87 & 75.55 & 657.15 & 74.05 & -0.33 & 2.40 \\
\hline RP3 & 2032.58 & 146.49 & 113.58 & 263.62 & 100.83 & 0.73 & 1.63 \\
\hline FM1 & 2249.04 & 74.37 & 93.61 & 482.59 & 113.32 & 0.94 & 3.47 \\
\hline FMla & 7562.19 & 156.72 & 145.94 & 865.89 & 87.74 & 1.08 & 2.79 \\
\hline
\end{tabular}

shallow-water Terebratula sinuosa brachiopods, the secondary shell layer of which consists of elongated calcite fibres that are resistant to diagenetic alteration (Veizer et al. 1999; Brand et al. 2003). According to Brand et al. (2003), who analysed trace elements composition on modern brachiopods from different oceans and the Mediterranean Sea, we have selected a $450 \mathrm{ppm}$ of $\mathrm{Sr}$ as a cut-off threshold, as well as $200 \mathrm{ppm}$ for Fe and Mn, to consider the brachiopod shells unaltered by diagenetic processes, thus reliable for SIS (Table 1). On the contrary, among the bivalves, pectinid shells have been demonstrated to be the most reliable ones to record the isotope composition of ambient water (Scasso et al. 2001; Brandano \& Policicchio 2012). In this case, according to Scasso et al. (2001), a cut-off threshold of $650 \mathrm{ppm}$ of Sr, and of $200 \mathrm{ppm}$ for Fe and $\mathrm{Mn}$, has been chosen to determine diagenetic alteration of the samples (Table 1).

Oxygen isotope ratios measured on both the pectinid and brachiopod specimens show all positive values, ranging from $+0.25 \%$ to $+3.47 \%$, while carbon isotope values span from $-0.33 \%$ to $+1.92 \%$ o (Table 1). These values all fall within the range of the marine precipitated carbonates (Weissert 1989; Weissert et al. 2008 and references therein), and thus, a strong diagenetic overprint is excluded.

\section{Sr isotope ratios and age model}

The age of the LL can be constrained on the basis of the underlying and the overlying units. The Bryozoan calcarenites and the hemipelagic marls can be ascribed to the late Burdigalian-late Serravallian time interval (Merola 2007; Brandano et al. 2016b). Furthermore, the T. multiloba marls, which cap the LL, are early Messinian in age, as well as the upper LL (RML2), based on the occurrence of the Bulimina echinata (Sprovieri et al. 1996; Blanc-Valleron et al. 2002; Kouwenhoven et al. 2006; Violanti et al. 2013). Thus, the LL is Tortonian to early Messinian in age, although the absence of B. echinata in RML1 sample might be due to ecological factors. The foraminiferal assemblage (dominated by Elphidium and Asterigerinata spp.) suggests oligothrophic conditions and vegetated bottom not suitable for the euthrophic infaunal taxa like buliminids (Jorissen 1987; Murray 2006).

According to SIS, CAP 0 and CAP 3 pectinid samples, belonging to the base of the lower LL of the Costa dell'Avignone stratigraphic section, indicate, respectively, a 8.48 and 8.59 Ma age (Table 2). On the contrary, samples RP1a, RP2, RP2a, representative of the central and upper portions of the lower LL in the Roccamorice section, show dispersed age values, spanning from 9.75 Ma to 18.29 Ma. Lasty, samples FM1 and FM1a, belonging to the uppermost portion of the LL, in the Fonte Macchialonga section, indicate, respectively, an age of $10.09 \mathrm{Ma}$ and 8.14 Ma (Table 2).

\section{Discussion}

\section{Stratigraphy}

The base of the LL can be ascribed to a late Tortonian age according to the ${ }^{87} \mathrm{Sr} /{ }^{86} \mathrm{Sr}$ values of CAP 0 and CAP 3 samples of the Costa dell'Avignone section (Fig. 3; Table 2). This age model is consistent with the published literature on this lithostratigraphical unit. Merola (2007) identifies the Neogloboquadrina group in the upper portion of the underlying lithostratigraphical unit (the Orbulina Marls or the hemipelagic limestones and calcareous marls unit as defined in Brandano et al. 2016b). The Neogloboquadrina group has been recognized in the Monte dei Corvi section (GSSP of the Tortonian stage) just below the Serravallian-Tortonian boundary (Hilgen et al. 2005). Thus, the base of the LL cannot be older than early Tortonian. According to this age model of the Orbulina Marls, Patacca et al. 
Table 2. ${ }^{87} \mathrm{Sr} /{ }^{86} \mathrm{Sr}$ values of the pectinid and brachiopod shell samples reported with related analytical error $\left(2 \sigma_{\text {mean }}\right) ;{ }^{87} \mathrm{Sr} /{ }^{86} \mathrm{Sr}$ corrected ratios reported with the mean standard error $(2 \sigma)$ and the associated age values. Deviation from sea water ${ }^{87} \mathrm{Sr} /{ }^{86} \mathrm{Sr}\left(\varepsilon_{\mathrm{Sr}}\right)$ in parts per 10000 with an ${ }^{87} \mathrm{Sr} /{ }^{86} \mathrm{Sr}$ value of 0.709168 as measured at GEO during the same period as the samples. Numerical ages are reported from McArthur et al. (2001, see table version 4B: 08/04). Minimum and maximum ages were calculated by combining the long-term standard error $(2 \sigma)$ of each measured ${ }^{87} \mathrm{Sr} /{ }^{86} \mathrm{Sr}$ ratio with the uncertainty related to the strontium-isotope curve Howart \& McArthur (1997).

\begin{tabular}{llllllrrr}
\hline Sample & $\left({ }^{87} \mathrm{Sr} /{ }^{86} \mathrm{Sr}\right)$ & $2 \sigma_{\text {mean }}\left(\times 10^{-6}\right)$ & $\left({ }^{87} \mathrm{Sr} /{ }^{86} \mathrm{Sr}\right)^{1}$ & $2 \sigma\left(\times 10^{-6}\right)^{2}$ & Minimum age & Age $(\mathrm{Ma})$ & Maximum age & $\left(\varepsilon_{\mathrm{Sr}}\right)_{\mathrm{SW}}{ }^{3}$ \\
\hline CAP0 & 0.708908 & 7 & 0.708927 & 14 & 7.34 & 8.48 & 9.43 & $-3.40 \pm 0.14$ \\
CAP3 & 0.708906 & 4 & 0.708925 & 14 & 7.41 & 8.59 & 9.49 & $-3.43 \pm 0.14$ \\
RP1a & 0.708876 & 5 & 0.708895 & 14 & 9.33 & 9.75 & 10.15 & $-3.85 \pm 0.14$ \\
RP2 & 0.708679 & 6 & 0.708698 & 14 & 16.02 & 16.36 & 16.72 & $-6.63 \pm 0.14$ \\
RP2a & 0.708547 & 4 & 0.708567 & 14 & 18.03 & 18.29 & 18.53 & $-8.47 \pm 0.14$ \\
FM1 & 0.708864 & 5 & 0.708883 & 14 & 9.49 & 10.09 & 10.74 & $-4.02 \pm 0.14$ \\
FM1a & 0.708913 & 6 & 0.708932 & 14 & 7.17 & 8.14 & 9.25 & $-3.33 \pm 0.14$
\end{tabular}

${ }^{1}$ Corrected ${ }^{87} \mathrm{Sr} /{ }^{86} \mathrm{Sr}$ assuming a NBS 987 value of 0.710245 while our measured NBS 987 value was $0.710226 \pm 0.000014(n=12)$.

${ }^{2}$ External precision based on repeated measurements of NBS 987 during the course of the study gave a value $0.710226 \pm 0.000014$ $(n=12,2 \mathrm{SD})$.

${ }^{3}$ Deviation from sea water ${ }^{87} \mathrm{Sr} /{ }^{86} \mathrm{Sr}$ in parts per 10000 with an ${ }^{87} \mathrm{Sr} /{ }^{86} \mathrm{Sr}$ vale of 0.709168 as measured at GEO during the same period as the samples.

(2013) identify the discontinuity surface between the Orbulina Marls and the LL units as the maximumregressive surface of the Tor2 Global T-R Sequence of Snedden \& Liu (2011), dated at 9.32 Ma. The LL unit represents the following transgression phase during the Tor2 after 9.32 Ma (Patacca et al. 2013; Brandano et al. 2016a,b). The upper interval of the LL can be referred to the early Messinian on the basis of the occurrence of the Bulimina echinata (Sprovieri et al. 1996; Blanc-Valleron et al. 2002).

The ${ }^{87} \mathrm{Sr} /{ }^{86} \mathrm{Sr}$ ratios of the upper LL show very dispersed values giving an age that is not coherent with the stratigraphy, but being generally older than expected (Table 2; Fig. 7).

\section{The role of palaeoceanography and palaeogeography on Sr isotope record}

The difference between the Central Mediterranean and the global Sr isotope values during early Messinian is likely due to the progressive establishment of restricted marine conditions within the LL carbonate ramp, which limited the water exchanges and the mixing with the larger Mediterranean water body and, consequently, the Atlantic Ocean.

Mediterranean water circulation and chemistry have been affected by its geodynamic evolution during the Miocene. The closure of Indo-Pacific seaway started during the early Miocene and definitely closed after the Langhian-Serravallian transition, leaving the Mediterranean Sea exchanging only with the Atlantic Ocean (Rögl 1999; Kocsis et al. 2008) (Fig. 8). Kocsis et al. (2008) evidenced a Sr isotope anomaly trend, proposing restricted water circulation for the Mediterranean at least until $15 \mathrm{Ma}$. Successively, during the Messinian, the western connection with the Atlantic consisted in different

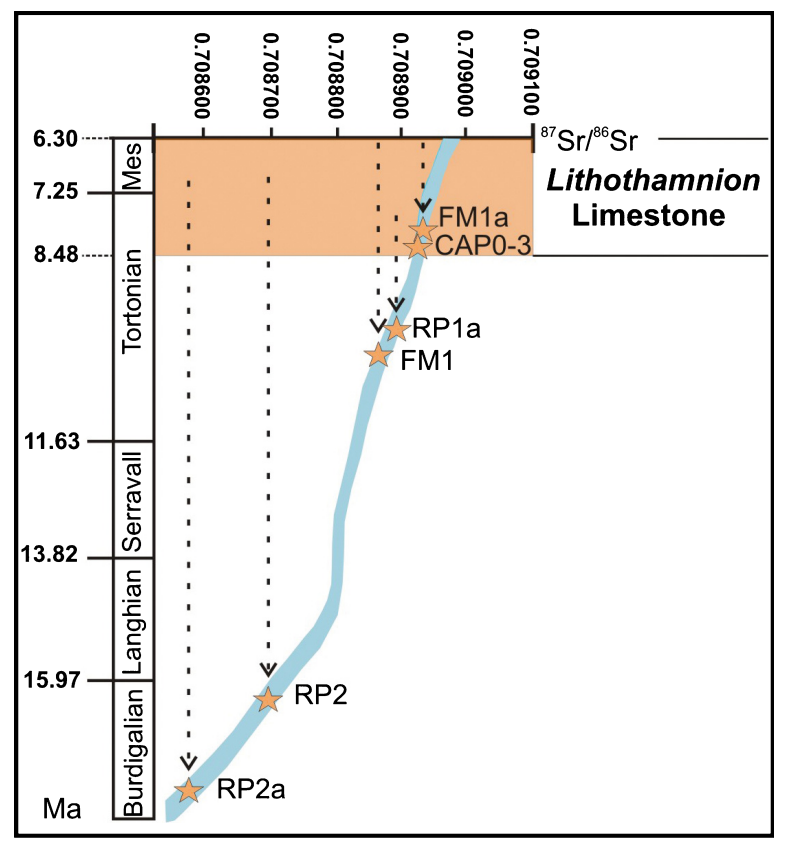

Fig. 7. Compilation of the Sr isotope data from this work. Light blue shaded region shows global sea water $\mathrm{Sr}$ isotope global reference line (from McArthur \& Howarth 2004). Orange column shows the stratigraphic position of the Lithothamnion Limestone (LL) unit according to the new age constraints: the $8.48 \mathrm{Ma}$ for the base derives from new SIS data provided in this article; the 6.30 Ma for the top refers to the CO of the Turborotalita multiloba according to Kouwenhoven et al. (2006). The orange stars represent the Sr isotope values of the measured samples. As it is shown in the figure, CAP 0 and CAP 3 samples fit with the age constraints of the LL, while the other samples show lower Sr isotope ratios in comparison with their age. The dashed indicators show how each sample is shifted from its correct stratigraphic position.

short-living, tectonically controlled, narrow straits and passages within the Betic area and the Rifian corridor (Betzler et al. 2006; Martín et al. 2009). In this oceanographical scenario, the Mediterranean 


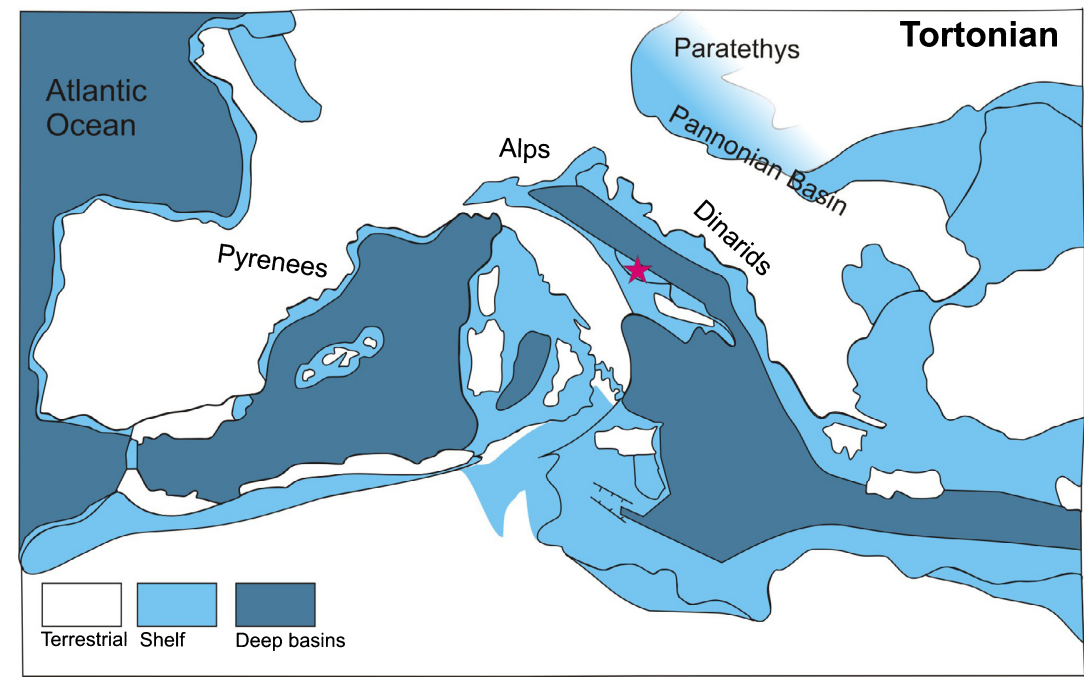

Fig. 8. Palaeogeographical map of the Mediterranean area during the Tortonian with location of the Majella carbonate platform (modified after Carminati et al. 2010).

basin starts facing progressive restricted conditions and partial isolation since $3 \mathrm{Myr}$ prior to the onset of the Messinian salinity crisis, even if surface water salinity remains frankly marine up until $200 \mathrm{kyr}$ prior the beginning of the deposition of the Lower Evaporites (Blanc-Valleron et al. 2002). Thus, the latemost Tortonian-early Messinian time interval is characterized by a large Central Mediterranean water body which was still connected with the Atlantic Ocean; it maintained oligotrophic water conditions and a $\mathrm{Sr}$ isotope signature comparable with that of the mean global ocean, and within the range of the McArthur et al. (2001) reference line. Late Tortonian-early Messinian time interval is characterized by the development of different types of reefs within the Mediterranean area. The best examples are located in Western Mediterranean, within the Betic, Balearic, Rif and Tell provinces (Braga et al. 1990; Braga \& Martín 1996; Esteban 1996; Esteban et al. 1996; Pomar et al. 2004, 2012), but they have also been found in the Central Mediterranean in the provinces of Toscana (Bossio et al. 1996), Calabria, Sicily and Malta (Pedley 1996), and in the southernmost portion of the Apulia carbonate platform, in the Salento area (Bosellini 2006).

Marginal sub-basins have limited water exchanges with the main larger water mass body (Flecker \& Ellam 2006; Topper et al. 2011; Schildgen et al. 2014). In this contest, the LL carbonate ramp succession records the evolution of trophic conditions in the proto-Adriatic marginal basin within the Mediterranean during late Miocene. This ramp is characterized by a completely different skeletal association, in comparison with the coeval Central Mediterranean platforms, which is dominated by coralline algae. This association has been interpreted as due to the evolving nutrient content of the central Adriatic waters.

Brandano et al. (2016a) distinguish three main stages in the evolution of the LL. In the first stage, the ramp established over the underlying hemipelagic marls and was subjected to repeated energy pulses within the inner ramp environment, very close to the vegetated area, where seagrass meadows established under oligotrophic conditions. The second stage is characterized by a progressive decrease of light penetration due to a progressive increase of fine continental derived sediments of the Apennine accretionary wedge. Seagrass meadows persisted within the inner ramp, interfingered with the maërl facies, which spread into the inner to middle ramp transition zone. The foraminiferal assemblage is dominated by Amphistegina, together with epiphytic small benthic foraminifera, indicating oligophotic conditions as well as a vegetated depositional environment. The third stage shows the decay of the trophic conditions faced in the ramp during the early Messinian, as testified by red algal growth form associated with an increase, towards the top of upper LL interval, of typical low oxygen foraminiferal taxa (Bulimina spp. and Bolivina/Brizalina spp., Valvulineria bradyana) tolerating abundant organic matter accumulation in dysoxic to anoxic conditions (van der Zwaan 1982; Jorissen 1987; Bernhard \& Sen Gupta 1999; Kouwenhoven et al. 2006; Frezza \& Carboni 2009). This is confirmed also by the increase in the planktonic fraction of Orbulina spp. (mainly O. bilobata) commonly recorded in the upper preevaporitic succession (Suc et al. 1995; Sprovieri 
et al. 1996; Blanc-Valleron et al. 2002; Violanti et al. 2013) and in water masses rich in high nutrient levels (Robbins 1988; Hemleben et al. 1989; Violanti et al. 2013). The increased nutrient content into the LL ramp has been referred to the Apennine accretionary wedge and foredeep system development and migration (Brandano et al. 2016a), which led to enhanced subsidence rates in the central Apennine platform domains and to an increased terrigenous input (Brandano \& Corda 2002). This is also suggested by the occurrence of agglutinated foraminiferal taxa (mainly Textularids) in the upper LL totally lacking in the underlying sample. Milli et al. (2007) showed that the first phase of the deposition of the turbidite succession of the Laga Basin is between 7.25 and $5.96 \mathrm{Ma}$, and it partially overlaps with the age the upper portion of the LL. Furthermore in the late Miocene, the Adriatic Sea was an elongated, shallow shelf-basin where continental input arrived from the North. This particular setting is analogous of today's Gulf of California (Mexico), where eutrophic water conditions are present in the northern sector. Here, bryozoans and molluscs dominate the skeletal assemblage. Moving southward, the nutrient content and organic matter of surface waters progressively decreases towards the southernmost portion of the gulf where corals develop into oligotrophic waters (Halfar et al. 2004, 2006). In the central portion of the gulf, within mesotrophic waters, red algae and molluscs are the main carbonate producers (Halfar et al. 2006).

Similar to the present Gulf of California, the LL ramp developed under mesotrophic conditions due to the progressively increasing terrigenous input from the North. In addition, progressive eastward migration of the Apennine accretionary wedge supported the development of restricted circulation of proto-Adriatic Sea due to its physiography, which led to a subsequent minor input of ocean waters and an enhanced continental influence. This restricted circulation, in turn, led its water chemistry to be significantly different from the larger Mediterranean water body not only for the nutrient content, but also impacted the Sr isotope signal, as shown by its isotope signature, which is lower than the coeval early Messinian global reference line (Fig. 7). The deviation of LL Sr isotope values could be attributed to environmental factors, given that its $\mathrm{Sr}$ isotope record is pristine and not due to any deuteric alteration, such as a relevant diagenetic overprint, which can be excluded for the studied samples. A significant input of freshwater, and continental run-off within a restricted basin, can lower the ${ }^{87} \mathrm{Sr} /{ }^{86} \mathrm{Sr}$ of the proto-Adriatic seawater. Flecker \& Ellam (2006) proposed a model where, in marginal Mediterranean sub-basins, only $50 \%$ of the water was of an Atlantic provenance, while the other half consisted in the riverine input, strongly affecting the local water chemistry and isotope signature. Schildgen et al. (2014) report Sr isotope values of different Mediterranean basins whose records show that, since the 98 Ma time interval, while the Central Mediterranean (Sicily, Malta, Cyprus) isotope signal is still strongly affected by the Atlantic influence, the eastern and the northern marginal basins are characterized by $\mathrm{Sr}$ isotope values lower than the contemporary mean Atlantic ones. Furthermore, these authors stated that this is due to the freshwater input and the continental derived sediments, together with the restricted circulation with the Central Mediterranean large water body, which controls the Sr isotope signal of these basins. This interpretation is supported by Böhme et al. (2008) palaeoclimatic reconstruction of the late Miocene of the southern-western Europe, which faced a progressive increase of humidity and precipitation rates from 8 to $5.3 \mathrm{Ma}$. In this case, an increased riverine water inflow within small marginal basins must have lowered its ${ }^{87} \mathrm{Sr} /{ }^{86} \mathrm{Sr}$ ratios. The Sr isotope signature of rivers reflects the lithologies cropping out within the river catchment areas. Thus, on a global scale weathering and continental run-off tend to raise ${ }^{87} \mathrm{Sr} /{ }^{86} \mathrm{Sr}$ ocean isotope ratios, given the high ${ }^{87} \mathrm{Sr} /{ }^{86} \mathrm{Sr}$ of most riverine waters that uptake Sr mainly from continental rocks or sediments, which are, on average, characterized by relatively high $\mathrm{Rb} / \mathrm{Sr}$ ratio and old ages. Within the Mediterranean different conditions were observed, as rivers had, and still have, mostly a northern catchment that drains Mesozoic shallow-water carbonates successions, which are marked by lower ${ }^{87} \mathrm{Sr} /{ }^{86} \mathrm{Sr}$ ratios than the late Miocene mean ones (Topper et al. 2011), and, in some cases, sedimentary formation containing significant amount of volcanoclastic component (e.g. Mattioli et al. 2012), with a ${ }^{87} \mathrm{Sr} /{ }^{86} \mathrm{Sr}$ ratio lower than seawater. Thus, in the study area, an increased amount of the influx of freshwaters, which in the Mediterranean have a lower $\mathrm{Sr}$ isotope signature than ocean seawaters (Schildgen et al. 2014), will result in a lowering of ${ }^{87} \mathrm{Sr} /{ }^{86} \mathrm{Sr}$. This is also in agreement with the Sr input trend through ground water of the modern western Mediterranean Sea (Trezzi et al. 2017). Investigating the Sr flux, these authors show how the Sr input is higher than to the global ocean, and the ${ }^{87} \mathrm{Sr} /{ }^{86} \mathrm{Sr}$ ratio is overall lower, due to the carbonate source of Sr to groundwater discharging.

According to Flecker \& Ellam (2006), a sea-level drop or salinity changes are considered to be the 
main controlling factors producing a deviation of $\mathrm{Sr}$ isotope values in restricted basins with respect to the global ocean values. On the contrary, the investigated succession records fully marine conditions and a progressive deepening upward trend, evolving from the LL ramp to the hemipelagic T. multiloba marls before the Messinian crisis. In this case, the physiography of the proto-Adriatic basin, strictly linked to the tectonic evolution of the area as well as climate and related fluvial run-off, mainly controlled the water chemistry. This is in agreement with the deviation of the Sr isotope signal of the upper Tortonian hemipelagic record of the Umbria-Marche region (Northern Apennines). In this succession, the $\mathrm{Sr}$ isotope ratios start deviating contemporary to the maximum uplift/exhumation rate of Apennine orogeny (Montanari et al. 1997).

\section{Conclusions}

Biostratigraphical constrains associated with SIS indicate a late Tortonian to early Messinian age for the Lithothamnion Limestone ramp succession cropping out in the Majella Mountain. However, this succession evidences a failure of SIS during latemost Tortonian and early Messinian because of a regional deviation of $\mathrm{Sr}$ isotope ratios from the global reference line.

The overall lower $\mathrm{Sr}$ isotope signature in comparison with the oceanic one has been interpreted as a hint of the progressive onset of restricted water exchanges between the Adriatic basin and the larger Mediterranean water body due to the local tectonic evolution, the narrow physiography of the protoAdriatic basin and its shallow-water column. In this framework, the enhanced freshwater input and continental run-off due to the migration of the accretionary wedge of the Apennine orogeny controlled the Sr isotope composition of this marginal basin, even if there is no evidence of salinity or major sealevel changes.

These results imply that not only a diagenetic overprint has to be ruled out prior to apply SIS on carbonate successions, but also an accurate oceanographical and geodynamic framework has to be taken into account before applying SIS on marginal basin successions, as in the case of an upper Miocene, central Apennines platform.

Acknowledgements. - The research leading to this article received support from Synthesys Programme, which is financed by the European Union's Seventh Framework Programme (FP7/20072013) under grant agreement no. 226506 (SYNTHESYS). Editor Peter Doyle and an anonymous reviewer are sincerely thanked for their comments and criticisms that improved the manuscript.
The Majella National Park, in particular in the person of Dr Elena Liberatoscioli, is sincerely thanked for the license to take samples within the park.

\section{References}

Andersson, P.S., Wassenburg, G.J. \& Ingri, J. 1992: The sources and transport of Sr and $\mathrm{Nd}$ isotopes in the Baltic Sea. Earth and Planetary Science Letters 113, 459-472.

Bernhard, J.M. \& Sen Gupta, B.K. 1999: Foraminifera of oxygendepleted environments. In Sen Gupta, B.K. (ed.): Modern Foraminifera, 201-216. Kluwer Academic Publishers, Dordrecht.

Betzler, C., Braga, J.C., Martín, J.M., Sanchez-Almazo, I.M. \& Lindhorst, S. 2006: Closure of a seaway: stratigraphic record and facies (Guadix basin, Southern Spain). International Journal of Earth Sciences 95, 903-910.

Blanc-Valleron, M.M., Pierre, C., Caulet, J.P., Caruso, A., Rouchy, J.M., Cespuglio, G., Sprovieri, R., Pestrea, S. \& Di Stefano, E. 2002: Sedimentary, stable isotope and micropaleontological records of paleoceanographic change in the Messinian Tripoli Formation (Sicily, Italy). Palaeogeography, Palaeoclimatology, Palaeoecology 185, 255-286.

Blow, W. 1969: Late-Middle Eocene to Recent planktonic foraminiferal biostratigraphy. In Bronniman, P. \& Renz, M.M. (eds): Proceeding of the First International Conference on Planktonic Microfossils, Genève 1967, pp. 199-421.

Bosellini, F.R. 2006: Biotic changes and their control on Oligocene-Miocene reefs: a case study from the Apulia Platform margin (southern Italy). Palaeogeography, Palaeoclimatology, Palaeoecology 241, 393-409.

Bossio, A., Esteban, M., Mazzanti, R., Mazzei, R. \& Salvatorini, G. 1996: Rosignano reef complex (Messinian), Livornesi Mountains, Tuscany, Central Italy. In Franseen, E.K., Esteban, M., Ward, W. \& Rouchy, J. (eds): Models for Carbonate Stratigraphy from Miocene Reef Complexes of Mediterranean Regions, volume 5, 277-294. SEPM Concepts in Sedimentology and Paleontology, Tulsa.

Böhme, M., Ilg, A. \& Winklhofer, M. 2008: Late Miocene 'washhouse' climate in Europe. Earth and Planetary Science Letters 275, 393-401.

Braga, J.C. \& Martín, J.M. 1996: Geometries of reef advance in response to relative sea-level changes in a Messinian (uppermost Miocene) fringing reef (Cariatiz reef, Sorbas Basin, SE Spain). Sedimentary Geology 107, 61-81.

Braga, J.C., Martin, J.M. \& Alcala, B. 1990: Coral reefs in coarseterrigenous sedimentary environments (Upper Tortonian, Granada Basin, southern Spain). Sedimentary Geology 66, 135-150.

Brand, U. \& Veizer, J. 1980: Chemical diagenesis of a multicomponent carbonate system-1: trace elements. Journal of Sedimentary Research 50, 1219-1236.

Brand, U., Logan, A., Hiller, N. \& Richardson, J. 2003: Geochemistry of modern brachiopods: applications and implications for oceanography and paleoceanography. Chemical Geology 198, 305-334.

Brandano, M. \& Corda, L. 2002: Nutrients, sea level and tectonics: constrains for the facies architecture of a Miocene carbonate ramp in central Italy. Terra Nova 14, 257-262.

Brandano, M. \& Policicchio, G. 2012: Strontium stratigraphy of the Burdigalian transgression in the Western Mediterranean. Lethaia 45, 315-328.

Brandano, M., Lipparini, L., Campagnoni, V. \& Tomassetti, L. 2012: Downslope-migrating large dunes in the Chattian carbonate ramp of the Majella Mountains (Central Apennines, Italy). Sedimentary Geology 255-256, 29-41.

Brandano, M., Tomassetti, L., Sardella, R. \& Tinelli, C. 2016a: Progressive deterioration of trophic conditions in a carbonate ramp environment: the Lithothamnion Limestone, Majella Mountain (Tortonian-early Messinian, Central Apennines, Italy). Palaios 31, 125-140.

Brandano, M., Cornacchia, I., Raffi, I. \& Tomassetti, L. 2016b: The Oligocene-Miocene stratigraphic evolution of the Majella 
carbonate platform (Central Apennines, Italy). Sedimentary Geology 333, 1-14.

Burke, W.H., Denison, R.E., Hetherington, E.A., Koepnick, R.B., Nelson, H.F. \& Otto, J.B. 1982: Variation of ${ }^{87} \mathrm{Sr} /{ }^{86} \mathrm{Sr}$ throughout Phanerozoic time. Geology 10, 516-519.

Carminati, E., Lustrino, M., Cuffaro, M. \& Doglioni, C. 2010: Tectonics, magmatism and geodynamics of Italy: what we know and what we imagine. In: Beltrando, M., Peccerillo, A., Mattei, M., Conticelli, S. \& Doglioni, C. (eds). The Geology of Italy. Journal of the Virtual Explorer, Electronic Edition, 36, paper 9.

Carnevale, G., Patacca, E. \& Scandone, P. 2011: Field guide to the post-conference excursions Scontrone, Palena and Montagna della Majella). R.C.M.N.S. Interim Colloquium, 4-5 March 2011, Scontrone (L’Aquila), Italy, pp. 1-99.

Cosentino, D., Cipollari, P., Marsili, P. \& Scrocca, D. 2010: Geology of the central Apennines: a regional review. In Beltrando M., Peccerillo A., Mattei M., Conticelli S. \& Doglioni C. (eds): The Geology of Italy. Journal of the Virtual Explorer. Electronic Edition. v. 36, paper 11.

Crescenti, U., Crostella, A., Donzelli, G. \& Raffi, G. 1969: Stratigrafia della serie calcarea dal Lias al Miocene nella regionemarchigiano abruzzese: Parte II. Litostratigrafia, biostratigrafia, paleogeografia. Memorie Della Società Geologica Italiana 9, 343-420.

Danese, E. 1999: Upper Miocene carbonate ramp deposits from the southernmost part of Maiella Nountain (Abruzzo, Central Italy). Facies 41, 41-54.

De Paolo, D.J. \& Ingram, B.L. 1985: High-resolution stratigraphy with strontium isotopes. Science 227, 938-941.

Esteban, M. 1996: An overview of Miocene reefs from Mediterranean areas: general trends and facies models. In Franseen, E.K., Esteban, M., Ward, W. \& Rouchy, J. (eds): Models for Carbonate Stratigraphy from Miocene Reef Complexes of Mediterranean Regions, volume 5, 3-53. SEPM Concepts in Sedimentology and Paleontology, Tulsa.

Esteban, M., Braga, J.C., Martín, J. \& De Santisteban, C. 1996: Western Mediterranean reef complexes. In Franseen, E.K., Esteban, M., Ward, W. \& Rouchy, J. (eds): Models for Carbonate Stratigraphy from Miocene Reef Complexes of Mediterranean Regions, volume 5, 55-72. SEPM Concepts in Sedimentology and Paleontology, Tulsa.

Faure, G. 1986: Principles of Isotope Geochemistry. John Wiley, Chichester.

Flecker, R. \& Ellam, R.M. 2006: Identifying late Miocene episodes of connection and isolation in the Mediterranean-Paratethyan realm using Sr isotopes. Sedimentary Geology 188-189, 189203.

Flecker, R., de Viellers, S. \& Ellam, R.M. 2002: Modelling the effects of evaporation on the salinity ${ }^{87} \mathrm{Sr} /{ }^{86} \mathrm{Sr}$ relationship in modern and ancient marginal-marine systems: the Mediterranean Messinian Salinity Crisis. Earth and Planetary Science Letters 203, 221-233.

Frezza, V. \& Carboni, M.G. 2009: Distribution of recent foraminiferal assemblages near the Ombrone River mouth (Northern Tyrrhenian Sea, Italy). Revue de Micropaléontologie 52, 43-66.

Frijia, G. \& Parente, M. 2008: Strontium isotope stratigraphy in the upper Cenomanian shallow-water carbonates of the southern Apennines: short-term perturbations of marine $87 \mathrm{Sr} / 86 \mathrm{Sr}$ during the oceanic anoxic event 2. Palaeogeography, Palaeoclimatology, Palaeoecology 261, 15-29.

Frijia, G., Parente, M., Di Lucia, M. \& Mutti, M. 2015: Carbon and strontium isotope stratigraphy of the Upper Cretaceous (Cenomanian-Campanian) shallow-water carbonates of southern Italy: chronostratigraphic calibration of larger Foraminifera biostratigraphy. Cretaceous Research 53, 110-139.

Halfar, J., Godinez-Orta, L., Mutti, M., Valdez-Holguín, J.E. \& Borges, J.M. 2004: Nutrient and temperature controls on modern carbonate production: an example from the Gulf of California, Mexico. Geology 32, 213-216.

Halfar, J., Godinez-Orta, L., Mutti, M., Valdez-Holguin, J.E. \& Borges, J.M. 2006: Carbonates calibrated against oceanographic parameters along a latitudinal transect in the Gulf of California, Mexico. Sedimentology 53, 297-320.

Hemleben, C., Spindler, M. \& Anderson, O.R. 1989: Modern Planktonic Foraminifera, 363 pp. Springer, New York.

Hilgen, F., Aziz, H.A., Bice, D., Iaccarino, S., Krijgsman, W., Kuiper, K., Montanari, A., Raffi, I., Turco, E. \& Zachariasse, W.J. 2005: The global boundary stratotype section and point (GSSP) of the Tortonian stage (Upper Miocene) at Monte Dei Corvi. Episodes-Newsmagazine of the International Union of Geological Sciences 28, 6-17.

Howart, R.J. \& McArthur, J.M. 1997: Statistics for strontium isotope stratigraphy with a look-up table version. The Journal of Geology 105, 441-456.

Iaccarino, S. 1985: Mediterranean Miocene and Pliocene planktic foraminifera. In Bolli, H.M., Saunders, J.B. \& Perch-Nielsen, K. (eds): Plankton Stratigraphy, 283-314. Cambridge University Press, Cambridge.

Immenhauser, A., Schöne, B.R., Hoffmann, R. \& Niedermayr, A. 2016: Mollusc and brachiopod skeletal hard parts: intricate archives of their marine environment. Sedimentology 63, 1-59.

Ingram, B.L. \& Sloan, D. 1992: Strontium isotopic composition of estuarine sediments as paleosalinity-paleoclimate indicator. Science 255, 68-72.

Jorissen, F.J. 1987: The distribution of benthic foraminifera in the Adriatic Sea. Marine Micropaleontology 12, 21-48.

Kocsis, L., Vennemann, T.W., Fontignie, D., Baumgartner, C. \& Montanari, A. 2008: Oceanographic and climatic evolution of the Miocene Mediterranean deduced from $\mathrm{Nd}, \mathrm{Sr}, \mathrm{C}$ e O isotope compositions of marine fossils and sediments. Paleoceanography 23, PA4211.

Kouwenhoven, T.J., Morigi, C., Negri, A., Giunta, S., Krijgsman, W. \& Rouchy, J.M. 2006: Paleoenvironmental evolution of the eastern Mediterranean during the Messinian: constraints from integrated microfossil data of the Pissouri Basin (Cyprus). Marine Micropaleontology 60, 17-44.

Lirer, F. 2000: A new technique for retrieving calcareous microfossils from lithified lime deposits. Micropaleontology 365-369.

Longman, M.W. 1980: Carbonate diagenetic textures from nearsurface diagenetic environments. AAPG Bulletin 64, 461-487.

Lustrino, M., Morra, V., Fedele, L. \& Franciosi, L. 2009: Beginning of the Apennine subduction system in central western Mediterranean: constraints from Cenozoic "orogenic" magmatic activity of Sardinia, Italy. Tectonics 28 , TC 5016, 1-23.

Martín, J.M., Braga, J.C., Aguirre, J. \& Puga-Bernabéu, Á. 2009: History and evolution of the North-Betic Strait (Prebetic Zone, Betic Cordillera): a narrow, early Tortonian, tidal-dominated, Atlantic-Mediterranean marine passage. Sedimentary Geology 216, 80-90.

Mattioli, M., Lustrino, M., Ronca, S. \& Bianchini, G. 2012: Alpine subduction imprint in Apennine volcaniclastic rocks. Geochemical-petrographic constraints and geodynamic implications from Early Oligocene Aveto-Petrignacola Formation (N Italy). Lithos 134-135, 201-220.

McArthur, J.M. 1994: Recent trends in strontium isotope stratigraphy. Terra Nova 6, 331-358.

McArthur, J.M. \& Howarth, R.J. 2004: Strontium isotope stratigraphy. In Gradstein, F., Ogg, J. \& Smith, A. (eds): A Geologic Time Scale, 96-105. Cambridge University Press, Cambridge.

McArthur, J.M., Howarth, R.J. \& Bailey, T.R. 2001: Strontium isotope stratigraphy: LOWESS version 3: best fit to the marine Sr-isotope curve for 0-509 $\mathrm{Ma}$ and accompanying look-up table for deriving numerical age. The Journal of Geology 109, 155-170.

McArthur, J.M., Howarth, R.J. \& Schields, G.A. 2012: Strontium isotope stratigraphy. In Gradstein, F.M., Ogg, J.G., Schmitz, M.D. \& Ogg, G.M. (eds): The Geologic Time Scale 2012, 207232. Elsevier, Amsterdam.

Merola, D. 2007: Biostratigrafia a foraminiferi planctonici dei depositi emipelagici dell'Oligocene Superiore/Miocene Inferiore (Calcari con Selce) e del Miocene Medio (Calcilutiti ad Orbulina) della Montagna della Maiella (Appennino centrale, Abruzzo). Unpublished $\mathrm{PhD}$ Thesis, Pisa. 
Milli, S., Moscatelli, M., Stanzione, O. \& Falcini, F. 2007: Sedimentology and physical stratigraphy of the Messinian turbidite deposits of the Laga basin (central Apennines, Italy). Bollettino Della Società Geologica Italiana 126, 255-281.

Montanari, A., Beaudoin, B., Chan, L.S., Coccioni, R., Deino, A., DePaolo, D.J., Emmanuel, L., Fornaciari, E., Kruge, M., Lundblad, S., Mozzato, C., Portier, E., Renard, M., Rio, D., Sandroni, P. \& Stankiewicz, A. 1997: Integrated stratigraphy of the Middle to Upper Miocene pelagic sequence of the Conero Riviera (Marche Region, Italy). In Montanari, A., Odin, G. \& Coccioni, R. (eds): Miocene Stratigraphy: An Integrated Approach, 409-450. Elsevier Science, Amsterdam.

Morse, J.W. \& Mackenzie, F.T. 1990: Geochemistry of sedimentary carbonates. Developments in Sedimentology, volume 48, 707 pp. Elsevier, Amsterdam.

Murray, J.W. 2006: Ecology and Applications of Benthic Foraminifera, 426 pp. Cambridge University Press, Cambridge.

Mutti, M., Bernoulli, D., Eberli, G.P. \& Vecsei, A. 1996: Depositional geometries and facies associations in an upper Cretaceous prograding carbonate platform margin (Orfento supersequence, Maiella, Italy). Journal of Sedimentary Research 66, 749-765.

Mutti, M., Bernoulli, D. \& Stille, P. 1997: Temperate carbonate platform drowning linked to Miocene oceanographic events: Maiella platform margin, Italy. Terra Nova 9, 122-125.

Mutti, M., Bernoulli, D., Spezzaferri, S. \& Stille, P. 1999: Lower and Middle Miocene carbonate facies in the central Mediterranean: the impact of paleoceanography on sequence stratigraphy. In Harris, P., Saller, A., Simo, J. \& Handford, C.R. (eds): Advances in Carbonate Sequence Stratigraphy: Application to Reservoirs, Outcrops and Models, SEPM SP 63, 371-384.

Palmer, M.R. \& Edmond, J.M. 1989: The strontium isotope budget of the modern ocean. Earth and Planetary Science Letters 92, 1126.

Patacca, E., Scandone, P., Di Luzio, E., Cavinato, G.P. \& Parotto, M. 2008: Structural architecture of the central Apennines: interpretation of the CROP 11 seismic profile from the Adriatic coast to the orographic divide. Tectonics 27, TC3006.

Patacca, E., Scandone, P. \& Carnevale, G. 2013: The Miocene vertebrate-bearing deposits of Scontrone (Abruzzo, Central Italy): stratigraphic and paleoenvironmental analysis. Geobios 46, 523.

Pedley, M. 1996: Miocene reef facies of the Pelagian region (Central Mediterranean). In Franseen, E.K., Esteban, M., Ward, W. \& Rouchy, J. (eds): Models for Carbonate Stratigraphy from Miocene Reef Complexes of Mediterranean Regions, volume 5, 247-260. SEPM Concepts in Sedimentology and Paleontology, Tulsa.

Pomar, L., Brandano, M. \& Westphal, H. 2004: Environmental factors influencing skeletal grain sediment associations: a critical review of Miocene examples from the western Mediterranean. Sedimentology 51, 627-651.

Pomar, L., Bassant, P., Brandano, M., Ruchonnet, C. \& Janson, X. 2012: Impact of carbonate producing biota on platform architecture: insights from Miocene examples of the Mediterranean region. Earth-Science Reviews 113, 186-211.

Robbins, L.L. 1988: Environmental significance of morphologic variability in open-ocean versus ocean-margin assemblages of Orbulina universa. Journal of Foraminiferal Research 18, 326333.

Rögl, F. 1999: Mediterranean and Paratethys. Facts and hypotheses of an Oligocene to Miocene paleogeography (short overview). Geologica Carpathica 50, 339-349.

Scasso, R.A., McArthur, J.M., Del Rio, C.J., Martınez, S. \& Thirlwall, M.F. 2001: ${ }^{87} \mathrm{Sr} /{ }^{86} \mathrm{Sr}$ Late Miocene age of fossil molluscs in the 'Entrerriense' of the Valdés Peninsula (Chubut, Argentina). Journal of South American Earth Sciences 14, 319-329.

Schildgen, T.F., Cosentino, D., Frijia, G., Castorina, F., Dudas, F.Ö., Iadanza, A., Sampalmieri, G., Cipollari, P., Caruso, A. \&
Strecker, M.R. 2014: Sea level and climate forcing of the Sr isotope composition of late Miocene Mediterranean marine basins. Geochemistry, Geophysics, Geosystems 15, 2964-2983.

Sirna, G. 1996: Brachiopodi miocenici dei dintorni di Scanno e della Maiella. Bollettino Della Società Paleontologica Italiana 5, 184-196.

Snedden, J.W. \& Liu, C. 2011: Recommendations for a uniform chronostratigraphic designation system for Phanerozoic depositional sequences. AAPG Bulletin 95, 1095-1122.

Sprovieri, R., Di Stefano, E., Caruso, A. \& Bonomo, S. 1996: High resolution stratigraphy in the Messinian Tripoli Formation in Sicily. Palaeopelagos 6, 415-435.

Steuber, T. 1999: Isotopic and chemical intra-shell variations in low-Mg calcite of rudist bivalves (Mollusca-Hippuritacea): disequilibrium fractionations and late Cretaceous seasonality. International Journal of Earth Sciences 88, 551-570.

Suc, J.-P., Violanti, D., Londeix, L., Poumot, C., Robert, C., Clauzon, G., Gautier, F., Turon, J.-L., Ferrier, J., Chikhi, H. \& Cambon, G. 1995: Evolution of the Messinian Mediterranean environments: the Tripoli Formation at Capodarso (Sicily, Italy). Review of Palaeobotany and Palynology 87, 51-79.

Taylor, A.S. \& Lasaga, A.C. 1999: The role of basalt weathering in the $\mathrm{Sr}$ isotope budget of the oceans. Chemical Geology 161, 199-214.

Topper, R.P.M., Flecker, R., Meijer, P.T. \& Wortel, M.J.R. 2011: A box model of the Late Miocene Mediterranean Sea: implications from combined $87 \mathrm{Sr} / 86 \mathrm{Sr}$ and salinity data. Paleoceanography 26, PA3223.

Trezzi, G., Garcia-Orellana, J., Rodellas, V., Masqué, P., GarciaSolsona, E. \& Andersson, P.S. 2017: Assessing the role of submarine groundwater discharge as a source of $\mathrm{Sr}$ to the Mediterranean Sea. Geochimica et Cosmochimica Acta 200, 4254.

Vecsei, A. \& Sanders, D.G. 1999: Facies analysis and sequence stratigraphy of a Miocene warm-temperate carbonate ramp, Montagna della Maiella, Italy. Sedimentary Geology 123, 103127.

Vecsei, A., Sanders, D.G.K., Bernoulli, D., Eberli, G.P. \& Pignatti, J. 1998: Cretaceous to Miocene sequence stratigraphy and evolution of the Maiella carbonate platform margin, Italy. In: Mesozoic and Cenozoic Sequence Stratigraphy of European Basins, SEPM Special Publication 60, 53-74.

Veizer, J., Buhl, D., Diener, A., Ebneth, S., Podlaha, O.G., Bruckschen, P., Jasper, T., Korte, C., Schaaf, M., Ala, D. \& Azmy, K. 1997: Strontium isotope stratigraphy: potential resolution and event correlation. Palaeogeography Palaeoclimatology Palaeoecology 132, 65-77.

Veizer, J., Ala, D., Azmy, K., Bruckschen, P., Buhl, D., Bruhn, F., Carden, G.A.F., Diener, A., Ebneth, S., Godderis, Y., Jasper, T., Korte, C., Pawellek, F., Podlaha, O.G. \& Strauss, H. 1999: ${ }^{87} \mathrm{Sr} /{ }^{86} \mathrm{Sr}, \delta^{13} \mathrm{C}$ and $\delta^{18} \mathrm{O}$ evolution of Phanerozoic seawater. Chemical Geology 161, 59-88.

Vezzani, L., Festa, A. \& Ghisetti, F.C. 2010: Geology and tectonic evolution of the Central-Southern Apennines, Italy. Geological Society of America Special Papers 469, 1-58.

Violanti, D., Lozar, F., Natalicchio, M., Dela Pierre, F., Bernardi, E., Clari, P. \& Cavagna, S. 2013: Stress-Tolerant Microfossils of a Messinian Succession from the Northern Mediterranean Basin (Pollenzo Section, Piedmont, Northwestern Italy), volume 52, 45-54. Bollettino della Società Paleontologica Italiana, Modena.

Weissert, H. 1989: C-isotope stratigraphy, a monitor of paleoenvironmental change: a case study from the Early Cretaceous. Surveys in Geophysics 10, 1-61.

Weissert, H., Joachimski, M. \& Sarnthein, M. 2008: Chemostratigraphy. Newsletter on Stratigraphy 42, 145-179.

Wenzel, B. 2000: Differential preservation of primary isotopic signatures in Silurian brachiopods from northern Europe. Journal of Sedimentary Research 70, 194-209.

van der Zwaan, G.J. 1982: Paleoecology of Late Miocene Mediterranean foraminifera. PhD Thesis, Utrecht University. 